\title{
The Use of Molecular-Sieving Materials as Ameliorant for Peat Degradation in the Tropics
}

\author{
Laksmita P. Santi'1, Didiek H. Goenadi' ${ }^{1}$, Supiandi Sabiham², ${ }^{2}$ azid Bindar $^{3}$ \\ ${ }^{1}$ Indonesian Research Institute for Biotechnology and Bioindustry, Bogor, Indonesia \\ ${ }^{2}$ Bogor Agricultural University, Bogor, Indonesia \\ ${ }^{3}$ Bandung Institute of Technology, Bandung, Indonesia \\ Email: laksmita.santi@gmail.com
}

How to cite this paper: Santi, L.P., Goenadi, D.H., Sabiham, S. and Bindar, Y. (2021) The Use of Molecular-Sieving Materials as Ameliorant for Peat Degradation in the Tropics. Journal of Minerals and Materials Characterization and Engineering, 9, 362-374.

https://doi.org/10.4236/jmmce.2021.94025

Received: May 21, 2021

Accepted: July 13, 2021

Published: July 16, 2021

Copyright $\odot 2021$ by author(s) and Scientific Research Publishing Inc. This work is licensed under the Creative Commons Attribution International License (CC BY 4.0).

http://creativecommons.org/licenses/by/4.0/

\begin{abstract}
Peat utilization for agriculture expansion area is commonly found extensively in tropical region during the last few decades. Most agronomical practices involve drainage resulting decomposition of organic materials and increasing drying. This study was carried out to determine the potential use of molecular-sieving materials (MPMs) as an ameliorant for peat soil targeted for reducing the potential hazard of peat degradation. A clinoptilolite-zeolite, empty fruit bunches of oil palm biochar (EFBOPB), and their combination were studied its characteristics to evaluate the ability in adsorbing water and green-house gas emission. A series of laboratory analyses were conducted to determine physicochemical and mineralogical characteristics of both materials and its combination, including elemental analyses, cation exchange capacity (CEC), $\mathrm{pH}$, pore spaces, water holding capacity (WHC), and adsorption capacity for $\mathrm{CO}_{2}, \mathrm{NH}_{3}$, and $\mathrm{N}_{2}$. The study revealed that $100-150$ mesh size of zeolite possesses higher values of CEC, WHC, and adsorption capacity for $\mathrm{CO}_{2}, \mathrm{NH}_{3}$, and $\mathrm{N}_{2}$ compared to $\mathrm{EFBOPB}$, whereas the latter indicated a higher organic-C content and pore spaces. Combination of $75 \%(\mathrm{w} / \mathrm{w})$ zeolite and 25\% (w/w) EFBOPB showed the best composition of these two MPMs to improve WHC of peat and as consequences slowing down the firing process of the peat. Based on the gas adsorption data, it could be assumed that the mixture of MPMs studied could be considered as an effective material to reduce risk of peat from fire potential hazard and retard GHG emission.
\end{abstract}

\section{Keywords}

Biochar, Clinoptilolite, Empty Fruit Bunches, Green-House Gas Emission 


\section{Introduction}

Peat land offers high potential alternative for agriculture production both for foods and feeds as well as for energy, particularly peat swampy forest dominated by tree species in which $65 \%$ of them are decomposed organic materials such as branches and roots and become bio-diversity, carbon (C), and water stocks [1] [2]. Indonesia has the largest area of tropical peat land, i.e., 13.43 million $\mathrm{Ha}$, whereas in a smaller area (2.6 million $\mathrm{Ha}$ ) is found in Malaysia [3] of which about 880 thousand Ha have been used for oil palm plantation [4]. It was indicative that land use and water management change in peat land area will promote higher level of peat degradation and influence $\mathrm{CO}_{2}$ and $\mathrm{CH}_{4}$ fluxes from the peat [5] [6]. According [7] $\mathrm{CO}_{2}$ emission in a peat land used as oil palm plantation was originated from subsoil layer up to $50 \mathrm{~cm}$ depth below un-waterlogged soil surface. From environmental view point, this phenomenon needs a serious attention to mitigate the negative impacts of such practices for oil palm plantation.

Efforts to mitigate the fast decomposition of peat and its corresponding green-house gas (GHG) emission have attracted many scientists over the world due to its capacity to save 40 to $90 \mathrm{Gt} \mathrm{C}$ and when it is mismanaged will create a serious environmental impact especially $\mathrm{C}$ emission to the atmosphere [8]. Basically, organic matter will be degraded due to aerobic decomposition and release $\mathrm{C}$ to the air. Therefore, official regulation issued by the National Peat Restoration Agency sets a rule that peat land use for agriculture activities must maintain the water level no more than $40 \mathrm{~cm}$ below soil surface. This policy creates limitation to the rooting zone of most crops except those belong to the wetland vegetation such as rice and mangrove. Some technologies were proposed to compromise the agronomical requirement versus official regulation namely so-called Aero-Hydro Culture [9] or paludiculture [10] claiming the cropping systems were still profitable by applying high water level condition. Furthermore, [11] reported that during dry season (April-August 2019) top soil layer $(0-20 \mathrm{~cm})$ of peat soil at water level $>40 \mathrm{~cm}$ still have $300 \%(\mathrm{w} / \mathrm{w})$ water content with bulk density $0.13 \mathrm{~g} \cdot \mathrm{cm}^{-3}$. Previous study also indicated that the use of molecular-sieving material (MPM) functioning as natural adsorbent combined with exopolysaccharide-producing microbes was capable of improving water holding capacity, aggregate stability, and oil palm yield up to $40 \%$ [12].

Zeolite and biochar are possessing considerably high inner pores which could act as spaces to retain water and gas [13] [14]. The Bayah-originating zeolite has been shown to be effective as oil-spill adsorbent [15], whereas biochar has also been reported for having similar properties as adsorbent [16]. However, the use of those two MPMs in combination has not been studied yet. This current study reports the potential use of selected MPMs such as a natural clinoptilolite-zeolite and biochar derived from empty fruit bunches of oil palm (EFBOPB) to minimize green-house gas $\left(\mathrm{CO}_{2}\right.$ and $\left.\mathrm{NH}_{3}\right)$ emission and land-fire hazard from peat soil used as oil palm plantation. A laboratory study was commenced with the objec- 
tives as follows: 1) physico-chemical and mineralogical characterization of MPMs; 2) evaluation of formulated MPM for $\mathrm{CO}_{2}$ and $\mathrm{NH}_{3}$ adsorption; and 3) improving water holding capacity to reduce land fire hazard. The results would be beneficial for developing applied technology to combat with negative environmental impacts caused by mismanaged peat utilization for agriculture including oil palm plantation.

\section{Material and Method}

\subsection{Physicochemical Characterization of MPMs}

A clinoptilolite-zeolite sample was obtained from Bayah natural deposit, Banten, whereas the EFBOPB was prepared by employing a slow-pyrolysis process with $300^{\circ} \mathrm{C}-400^{\circ} \mathrm{C}$ temperature for about eight hours [17] [18]. Three samples of zeolite analyzed consisted of three different particle sizes, i.e., 60 - 80, 80 - 100, and 100 - 150 mesh. The physical characterization included pore structure, pore space area, water and gas $\left(\mathrm{CO}_{2}\right.$ and $\left.\mathrm{N}_{2}\right)$ adsorption capacity by using BrunaerEmmet-Teller method [19] [20]. In contrast, the chemical properties were determined by using standard laboratory analyses outlined by SNI 13-3494-1994 (ICS 73.080), including $\mathrm{pH}$ (in water by $\mathrm{pH}$-meter), organic $\mathrm{C}$ (spectrophotometry), Nitrogen $(\mathrm{N})$ (Kjeldahl), Phosphate $\left(\mathrm{P}_{2} \mathrm{O}_{5}\right)$ (spectrophotometry), potassium $\left(\mathrm{K}_{2} \mathrm{O}\right)$ (integrated couple plasma, ICP), cation exchange capacity (titration), selected heavy metals and micro-nutrients (ICP), and bacterial contaminant E. coli and Salmonella (total plate counts). Both physical and chemical analyses were performed at Indonesian Research Institute for Biotechnology and Bioindustry, Bogor, Indonesia.

\subsection{Mineralogical Characteristics of MPMs}

Mineralogical composition of the best zeolite powder was determined by using $\mathrm{x}$-ray diffraction (XRD) analysis by running at $0^{\circ}-30^{\circ} 2-\theta$ with $\mathrm{Cu} \mathrm{Ka}$ at the Chemical Laboratory of the Indonesian Institute of Sciences (IIS) at Serpong, Banten. Identification of the mineral present was carried out by using major intensive peak characterizing the mineral according to [21]. To obtain particle surface appearances a scanning electron microscopy analysis was performed at the same laboratory. Both materials samples were examined with a Scanning Electron Microscope (SEM). The electron beam is accelerated through a high voltage $20 \mathrm{kV}$ and pass through a system of apertures and electromagnetic lenses to produce a thin beam of electrons [22]. In the early stages a material sample leveled with a special tool. After sputter coating the cast with $35 \mathrm{~nm}$ of gold-palladium (Au-Pd), electron micrographs were generated using a Jeol JSM-5310LV SEM.

\subsection{Determination of MPMs' Capacity in Gas Adsorption}

Adsorption capacity analyses of the Bayah zeolite and EFBOPB were performed by using $\mathrm{CO}_{2}$ and $\mathrm{N}_{2}$ adsorption analyses at Chemical Laboratory, IIS, Serpong, Banten, employing gas adsorption/desorption isotherm described as follow. 
Sample was pretreated by heating at $350^{\circ} \mathrm{C}$ for 90 minutes under Helium $(\mathrm{He})$ gas (inert) exposure. Adsorption of $\mathrm{CO}_{2}$ under $5 \%(\mathrm{v} / \mathrm{v}) \mathrm{He}$ was carried out at ambient temperature for 30 minutes followed by purging with Helium gas (inert) for 30 minutes at the same temperature. Desorption of $\mathrm{CO}_{2}$ was conducted at $100^{\circ} \mathrm{C}-700^{\circ} \mathrm{C}$ temperature with $10^{\circ} \mathrm{C} \cdot$ minute $^{-1}$ increment, hold at $700^{\circ} \mathrm{C}$ for 10 minutes. Gas flow rate was maintained at $30 \mathrm{~cm}^{3} \cdot$ minute $^{-1}$. Similar protocol was also applied for $\mathrm{N}_{2}$ adsorption measurement with gas flow rate of 40 $\mathrm{cm}^{3} \cdot$ minute $^{-1}$. Two MPMs combination were formulated, i.e., $75 \%$ zeolite 100 150 mesh $+25 \%$ EFBOPB and 50\% zeolite $100-150$ mesh $+50 \%$ EFBOPB $(\mathrm{w} / \mathrm{w})$, and subjected to gas and water adsorption analyses. As EFBOPB adsorb others gases on top of $\mathrm{CO}_{2}$, then the adsorption measurements of formulated MPMs were carried out in two conditions, with and without $\mathrm{CO}_{2}$ adsorption.

\subsection{Formulation of MPMs from Zeolite and EFBOPB}

The zeolite used in this experiment was originated from Bayah, Banten, calcinated at $150^{\circ} \mathrm{C}$ for four hours, and pyrolyzed EFBOP (EFBOP biochar or EFBOPB). Two formulations were made by using zeolite/biochar ratios of 50:50 and 75:25 (\% w/w). These formulas then inoculated by Bulkholderia cenocepacia, a superior exopolysaccharide-producing bacterium from IRIBB isolate collection which is capable of promoting a stable aggregation of peat soil using Bayah zeolite as carrier [23]. Fresh bacterial culture was prepared by growing the isolate on a $250 \mathrm{~mL}$ ATCC liquid medium consisting of $\left(\mathrm{L}^{-1}\right): 0.2 \mathrm{~g} \mathrm{KH}_{2} \mathrm{PO}_{4} ; 0.8$ $\mathrm{g} \mathrm{K}_{2} \mathrm{HPO}_{4} ; 0.2 \mathrm{~g} \mathrm{MgSO}_{4} \cdot 7 \mathrm{H}_{2} \mathrm{O} ; 0.1 \mathrm{~g} \mathrm{CaSO}_{4} \cdot 2 \mathrm{H}_{2} \mathrm{O} ; 2.0 \mathrm{mg} \mathrm{FeCl}{ }_{3} ; \mathrm{Na}_{2} \mathrm{MoO}_{4} \cdot 2 \mathrm{H}_{2} \mathrm{O}$ (trace); 0.5 g yeast extract; $20 \mathrm{~g}$ sucrose; and final $\mathrm{pH} 7.2$ and incubated for 48 72 hours at $30^{\circ} \mathrm{C}$. The innoculant was then inoculated into the MPM formulas at $5 \%(\mathrm{v} / \mathrm{w})$ concentration.

\subsection{Effect of MPMs Formula on Protecting Peat from Fire Hazard}

A simulation laboratorial study was carried out to determine the potential function of formulated MPMs in reducing the peat from fire hazard. The experiment used in-land peat from Ciamis, West Java, with decomposition level and bulk density of $0.3-0.4 \mathrm{~g} \cdot \mathrm{cm}^{-3}$, employing a method described by [24]. A special apparatus used was based on the design of IRIBB and Labodia. Parameters observed on peat treated with formulated MPM include speed and patter of fire creeps, water content, and bulk density. The burning test containment used is shown in Figure 1. It was made of stainless steel with $50 \times 50 \times 50 \mathrm{~cm}^{3}$ size, with inner divider of calcium silicate board and a burner was mounted in the left side with $400 \mathrm{~mm}$ length. Temperatures were measured by using thermocouple type $\mathrm{K}$ at nine different points i.e., three in each depth of 125,250 , and $375 \mathrm{~mm}$ at a distance of 75, 250, and $425 \mathrm{~mm}$. The thermocouple has $15 \mathrm{~mm}$ diameter with $500 \mathrm{~mm}$ probe length and accuracy of two degrees centigrade. Air flow to induce burning was facilitated by holes with $3.25 \mathrm{~cm}$ in diameter in other side of the container representing $1.8 \%$ openness of total area of the container. This property 


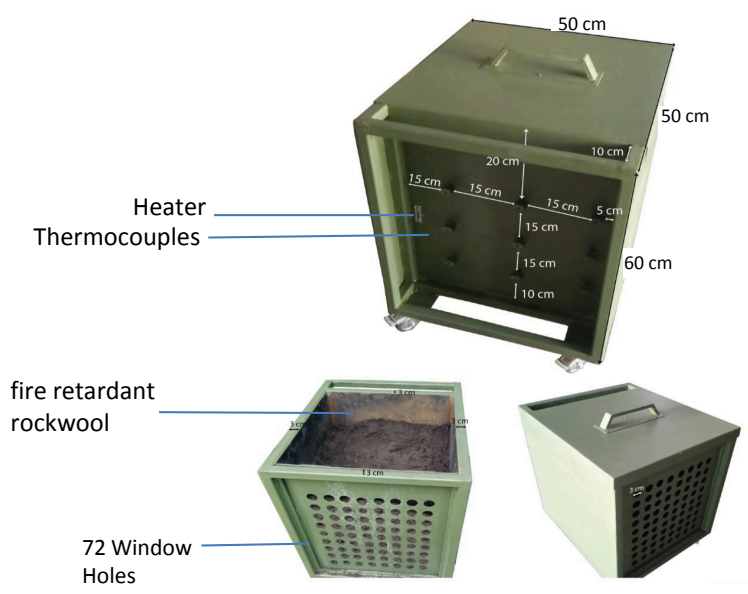

Figure 1. Burning reactor prototype for MPM-treated peat burning experiment in this study.

was designed in a specific size in order to provide airflow and to help maintain the perfect burning process. All treatments were recorded by using a Midi Logger GL240 to set electric power, temperature, and burning period. Burning media for this experiment were simulated by using the mixture of rice straw and coarse peat ( $1: 3$ and $3: 1 \mathrm{w} / \mathrm{w})$ with maximum water content of $15 \%$ and bulk density $0.4-0.5 \mathrm{~g} \cdot \mathrm{cm}^{-3}$. The addition of MPM material into the burning medium was zeolite or EFBOPB at $0 \% ; 1 \% ; 1.5 \% ; 2 \%$; and $2.5 \%(\mathrm{w} / \mathrm{w})$ rate and water content of $10.4 \%$ (zeolite) and 5.7\% (EFBOPB).

\section{Results and Discussion}

\subsection{Physicochemical Characterization of MPMs}

As shown in Table 1, both MPM materials studied have alkaline reaction in which the average $\mathrm{pH}$ values of zeolite (7.7) were lower than those of EFBOPB (9.5). In contrast, the contents of $\mathrm{N}$ and $\mathrm{K}$ were found higher in the former, whereas the opposite was true on the P content and CEC value. Based on the Indonesian Industrial Standard (SNI) for CEC value, the 100 - 150 mesh zeolite (126.45 $\mathrm{cmol}^{(+)} \cdot \mathrm{kg}^{-1}$ ) met the standard of SNI 13-7168-2006 (min 100 $\left.\mathrm{cmol}^{(+)} \cdot \mathrm{kg}^{-1}\right)$, whereas that of EFBOPB was far below of zeolite. However, as the MPMs formula at the end should met the minimum requirement of an inorganic soil ameliorant formula set by the Ministry of Agriculture, then it should be oriented to meet this standard as indicated in Table 1. According to this ministerial decree the contents of heavy metals and microbial contaminants in the MPM materials, except for CEC value of EFBOPB, passed the standard values. Based on this evidence, the formulation of MPMs consisting a mixture of 100 150 mesh zeolite and EFBOPB at 75:25 and 50:50 (\% w/w) composition was made and tested further. This study found that increasing the surface area of the zeolite to 100 - 150 mesh improves the physical and chemical reactions on the zeolite, resulting in a higher $\mathrm{CEC}$ value and release of $\mathrm{P}, \mathrm{K}$, and micronutrients (Fe, Mn, and $\mathrm{Zn}$ ) than $60-80$ or $80-100$ mesh. 
Table 1. Physico-chemical characteristics of MPM materials studied.

\begin{tabular}{|c|c|c|c|c|c|c|}
\hline \multirow{2}{*}{ Characteristics } & \multicolumn{5}{|c|}{ Type of MPM material } & \multirow{2}{*}{ Method } \\
\hline & EFBOPB & $\begin{array}{c}\text { Zeolite } \\
60-80 \text { mesh }\end{array}$ & $\begin{array}{c}\text { Zeolite } \\
80-100 \text { mesh }\end{array}$ & $\begin{array}{c}\text { Zeolite } \\
100-150 \text { mesh }\end{array}$ & $\begin{array}{c}\left.\text { Kepmentan }^{*}\right) \\
\text { 261/KPTS/SR.310/M/4/2019 }\end{array}$ & \\
\hline $\mathrm{pH}$ & 9.2 & 7.8 & 7.2 & 8.2 & $7-12$ & $\mathrm{pH}$ meter \\
\hline Organic C (\%) & 31.15 & 0.2 & 0.1 & 0.7 & 30 - 60 biochar & Spectrophotometry \\
\hline $\mathrm{N}(\%)$ & 1.4 & 0.013 & 0.012 & 0.013 & - & Kjedahl \\
\hline $\mathrm{P}_{2} \mathrm{O}_{5}(\mathrm{ppm})$ & 0.3 & 27.9 & 36.1 & 89.92 & - & Spectrophotometry \\
\hline $\mathrm{K}_{2} \mathrm{O}(\%)$ & 2.7 & 1.54 & 1.58 & 1.75 & - & ICP \\
\hline $\operatorname{CEC}\left(\mathrm{cmol}^{(+)} \cdot \mathrm{kg}^{-1}\right)$ & 26.2 & 70.35 & 86.97 & 126.45 & Min.60 & Titration \\
\hline Particle size (nm) & 4324.448 & 74.3346 & 73.5550 & 71.4413 & - & BET \\
\hline E. coli $\left(\mathrm{MPNg}^{-1}\right)$ & $<3$ & $<3$ & $<3$ & $<3$ & $<3$ & TPC \\
\hline Salmonella $\left(\mathrm{MPNg}^{-1}\right)$ & $<3$ & $<3$ & $<3$ & $<3$ & $<3$ & TPC \\
\hline As (ppm) & $\mathrm{Nd}^{* *}$ & $\mathrm{Nd}$ & $\mathrm{Nd}$ & $\mathrm{Nd}$ & 10 & ICP \\
\hline $\mathrm{Hg}(\mathrm{ppm})$ & $\mathrm{Nd}$ & $\mathrm{Nd}$ & $\mathrm{Nd}$ & $\mathrm{Nd}$ & 1 & ICP \\
\hline $\mathrm{Cd}(\mathrm{ppm})$ & 0.2 & $\mathrm{Nd}$ & $\mathrm{Nd}$ & $\mathrm{Nd}$ & 2 & ICP \\
\hline $\mathrm{Pb}(\mathrm{ppm})$ & 4.3 & 3.48 & 3.34 & 3.38 & 50 & ICP \\
\hline $\mathrm{Fe}(\mathrm{ppm})$ & 584.5 & 88.45 & 93.24 & 105.34 & Min. 7 & ICP \\
\hline $\mathrm{Mn}(\mathrm{ppm})$ & 367.1 & 8.96 & 10.52 & 30.38 & - & ICP \\
\hline $\mathrm{Zn}(\mathrm{ppm})$ & 11.9 & 1.34 & 1.5 & 2.06 & - & ICP \\
\hline $\mathrm{Ni}(\mathrm{ppm})$ & 3.62 & $\mathrm{Nd}$ & $\mathrm{Nd}$ & $\mathrm{Nd}$ & Max.50 & ICP \\
\hline $\mathrm{Cr}(\mathrm{ppm})$ & 7.2 & 0.20 & 0.29 & 0.32 & Max.180 & ICP \\
\hline
\end{tabular}

"Indonesian Agriculture Ministerial Decree, ${ }^{* *} \mathrm{Nd}$ (Not detected).

\subsection{Mineralogical Characteristics of MPMs}

Based on X-ray diffractograms (XRDs) shown in Figure 2, it is indicative that the Bayah natural zeolite was dominated by a clinoptilolite with poly-cations $\mathrm{K}-\mathrm{Mg}$ [K5.17 Mg0.16 (Al6 Si30 O72). 24 $\mathrm{H}_{2} \mathrm{O}$ ]. There were no significant different in the indicative peaks showing the presence of the mineral among the three particles size analyzed i.e., at the $2 \theta$ position corresponding to $9.8,22.3$, and $25.6 \AA$ particle diameters [15]. However, a smaller size particle tends to produce a background noise in the XRDs. On the other hand, the SEM analyses showed that the MPM formula containing 100 - 150 mesh zeolite particles were aggregated after inoculated with B. cenocepacia (Figure 3). It is indicative that EFBOPB has larger pore sizes compared those of zeolites as shown in Table 1. However, the diameter sizes of pores in zeolite tend to be bigger with decreasing particle size of the mineral. As the capacity of adsorption is directly related to the pores volume, then the 100 - 150 mesh particle was chosen as MPM formula component. 


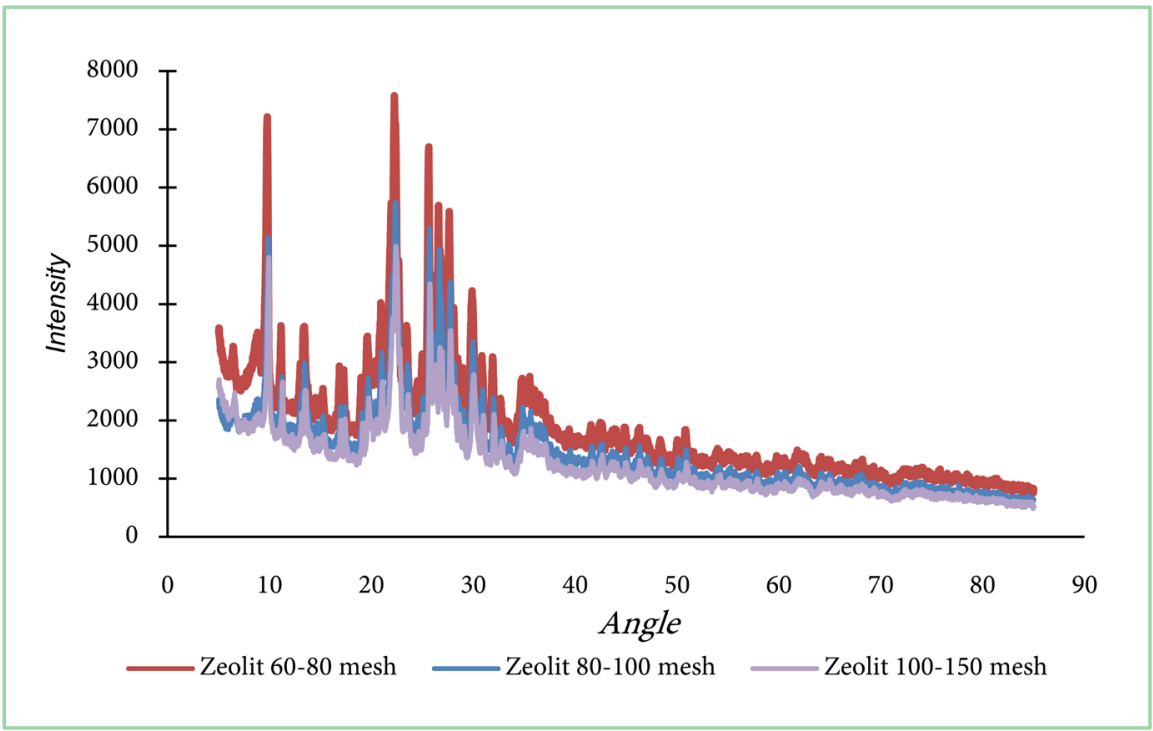

Figure 2. X-ray diffractograms of Bayah zeolite with three different particle sizes.

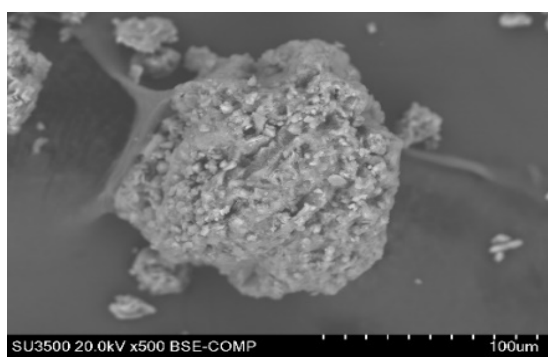

(a)

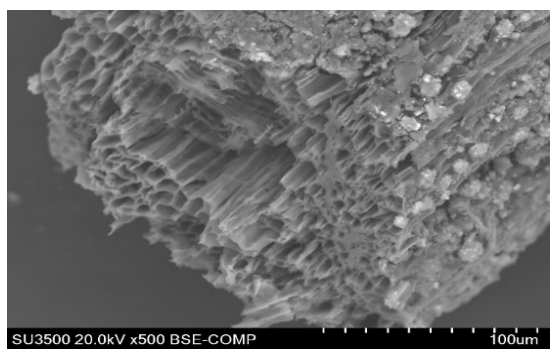

(c)

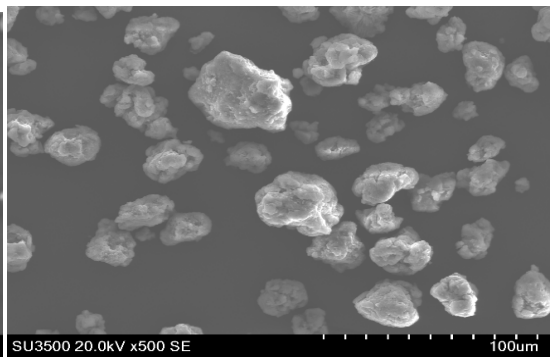

(b)

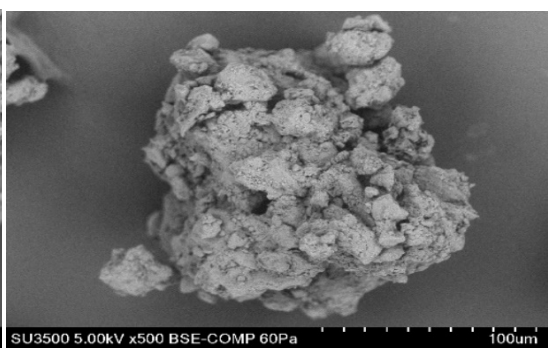

(d)

Figure 3. Scanning electron photomicrographs of a 60 - 80 mesh zeolite particle (a), a 100 - 150 mesh zeolite (b), EFBOPB particle (c), and inoculated with exopolysaccharide-producing bacteria (d). Mag. 500x.

\subsection{Gas Adsorption Capacity}

Data shown in Table 2 are the values of $\mathrm{CO}_{2}$ and $\mathrm{NH}_{3}$ gases each adsorbed by each MPMs studied. Zeolite material can adsorb $\mathrm{CO}_{2}$ or $\mathrm{NH}_{3}$ alone without any other gases involved, whereas the EFBOPB adsorbs more other gases (unidentified) than $\mathrm{CO}_{2}$ or $\mathrm{NH}_{3}$. Therefore, the measurement of gases adsorption capacity of the EFBOPB was carried out with and without $\mathrm{CO}_{2}$ or $\mathrm{NH}_{3}$ adsorption. The net $\mathrm{CO}_{2}$ or $\mathrm{NH}_{3}$ adsorption was then obtained by the different of the two measurements. It is indicative that $100-150$ mesh zeolites adsorb $\mathrm{CO}_{2}$ and $\mathrm{NH}_{3}$ 
Table 2. Adsorption of $\mathrm{CO}_{2}$ and $\mathrm{NH}_{3}$ gas by zeolite, biochar, and the combination of zeolite and biochar formulated (50:50 and 75:25).

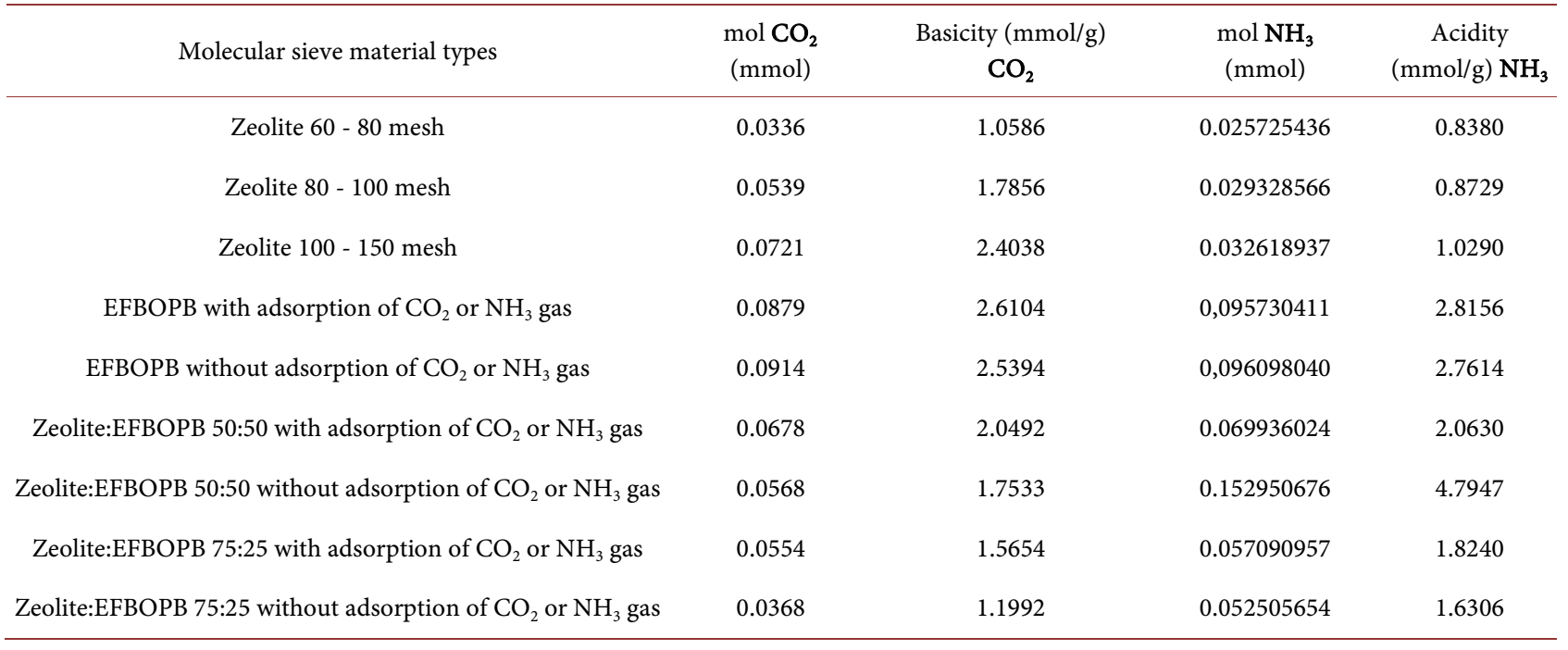

more than those by smaller particle sizes, whereas EFBOPB adsorb other gases $\left(2.54 \mathrm{mmol} \cdot \mathrm{g}^{-1} \mathrm{CO}_{2}\right.$ and $\left.2.76 \mathrm{mmol} \mathrm{NH} \mathrm{NH}_{3}\right)$ more than $\mathrm{CO}_{2}\left(0.08 \mathrm{mmol} \cdot \mathrm{g}^{-1}\right)$ or $\mathrm{NH}_{3}\left(0.05 \mathrm{mmol} \cdot \mathrm{g}^{-1}\right)$ and the total values $\left(2.61 \mathrm{mmol} \mathrm{CO} \mathrm{g}^{-1}\right.$ and $2.81 \mathrm{mmol}$ $\mathrm{NH}_{3} \mathrm{~g}^{-1}$ ) were higher than those of the zeolites (1.06 to $2.40 \mathrm{mmol} \mathrm{CO}_{2}$ and 0.84 mmol to $1.03 \mathrm{mmol} \mathrm{NH}_{3} \mathrm{~g}^{-1}$ ). However, addition of zeolite into EFBOPB in formulated MPM improved the capacity of MPM in adsorbing the gases (2.05 and $1.56 \mathrm{mmol} \mathrm{CO}_{2} \mathrm{~g}^{-1}$ and 2.06 and $1.82 \mathrm{mmol} \mathrm{NH}_{3} \mathrm{~g}^{-1}$ for formula 50:50 and 75:25, respectively). The mechanism causing this phenomenon is unclear yet. Theoretically, in 50:50 formula, the proportion of adsorbing capacity supposed to be $1.24 \mathrm{mmol} \mathrm{CO}_{2} \mathrm{~g}^{-1}$ and $0.54 \mathrm{mmol} \mathrm{NH}_{3} \mathrm{~g}^{-1}$. On the other hand, these values become $1.67 \mathrm{mmol} \mathrm{CO}_{2} \mathrm{~g}^{-1}$ and $0.52 \mathrm{mmol} \mathrm{NH}_{3} \mathrm{~g}^{-1}$ in the $75: 25$ formula. It is assumed that the capacity of gases adsorption is related to the physical characteristics of the MPM i.e., volume in pores and total area pores. A regression analysis presented in Figure 4 shows that both $\mathrm{CO}_{2}$ and $\mathrm{NH}_{3}$ adsorption capacities were highly correlated more with volume in pores compared to the total area pores. This evidence was presumably indicating that the adsorption mechanism was more physically in nature rather than electrostatically.

Furthermore, synthetic nitrogen $(\mathrm{N})$ fertilizers, widely used in agricultural and plantation crop fertilization, are a significant source of greenhouse gas emissions. It is commonly assumed that the use of this $\mathrm{N}$ fertilizer significantly contributes to the cause of $\mathrm{N}_{2} \mathrm{O}$ emissions from the soil. Agricultural and plantation cultivation technology have advanced considerably in recent years and various efforts have been made in to reduce greenhouse gas emissions, including reducing fertilizer dosage and utilizing soil microorganisms to increase fertility and land productivity. According to research [25], an equivalent emission of 1052.26 - $1209.51 \mathrm{~kg} \mathrm{CO}_{2}$-eq ha ${ }^{-1}$ for each release of $\mathrm{N}_{2} \mathrm{O}$ between $19.11-22.17 \mathrm{~kg}$ $\mathrm{N}_{2} \mathrm{O}-\mathrm{N} \mathrm{ha}^{-1}$. According to the Intergovernmental Panel on Climate Change [26], 
one percent of $\mathrm{N}_{2} \mathrm{O}-\mathrm{N}$ emissions are caused by the total $\mathrm{N}$ applied during fertilization. Based on the findings of the preceding study, additional research on the impact of using $\mathrm{N}$ fertilizers and practical efforts are required. This study investigated the potential use of zeolite and its combination with EFBOPB as a molecular sieve material for adsorbing $\mathrm{N}_{2}$ gas. When compared to $80-100$ mesh $\left(71.7 \mathrm{~cm}^{3} \cdot \mathrm{g}^{-1} \mathrm{STP}\right)$ and $60-80$ mesh $\left(67.7 \mathrm{~cm}^{3} \cdot \mathrm{g}^{-1} \mathrm{STP}\right)$, zeolites with particle sizes of 100 - 150 mesh have a higher adsorption capacity $\left(75.6 \mathrm{~cm}^{3} \cdot \mathrm{g}^{-1} \mathrm{STP}\right)$ of $\mathrm{N}_{2}$ (Table 3). This confirms the previous results showing that the smaller the size of zeolite the higher the capacity in gas adsorption.

Table 3. Data analysis adsorption $\mathrm{N}_{2}$ from molecular sieve materials.

\begin{tabular}{ccccc}
\hline $\begin{array}{c}\text { Molecular sieve } \\
\text { material types }\end{array}$ & $\begin{array}{c}\text { Volume in pores } \\
\left(\mathrm{cm}^{3} \cdot \mathrm{g}^{-1}\right)\end{array}$ & $\begin{array}{c}\text { Total area in } \\
\text { pores }\left(\mathrm{m}^{2} \cdot \mathrm{g}^{-1}\right)\end{array}$ & $\begin{array}{c}\text { Median pore } \\
\text { width }(\mathrm{nm})\end{array}$ & $\begin{array}{c}\text { Quantity Adsorbed } \\
\left(\mathrm{cm}^{3} \cdot \mathrm{g}^{-1} \mathrm{STP}\right)\end{array}$ \\
\hline Zeolite $60-80$ mesh & 0.02589 & 14.873 & 12.9586 & 67.6803 \\
Zeolite $80-100$ mesh & 0.02271 & 17.172 & 15.3243 & 71.7037 \\
Zeolite 100 - 150 mesh & 0.02431 & 16.440 & 17.0669 & 75.7572 \\
EFBOPB & 0.00039 & 0.153 & 82.5952 & 1.6609 \\
Zeolite:EFBOPB 50:50 & 0.00083 & 9.108 & 33.1214 & 31.9866 \\
Zeolite:EFBOPB 75:25 & 0.00112 & 8.434 & 60.8470 & 43.7393
\end{tabular}

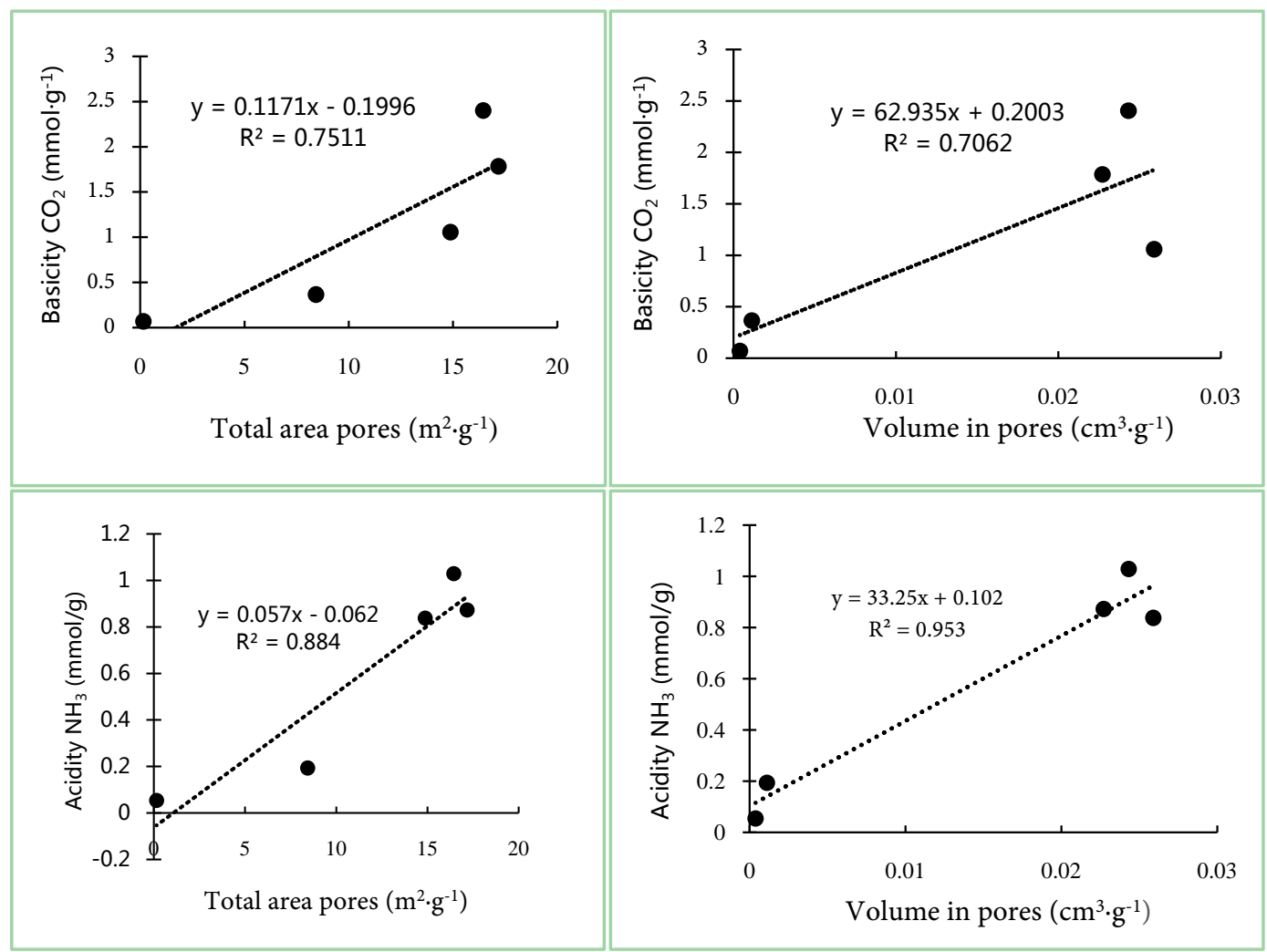

Figure 4. Correlation between gas adsorption capacity and total area pores (left) and volume in pores (right). 


\subsection{Effect of MPMs on WHC}

One of the final objectives of incorporating the MPMs on the peat soils is to reduce the potential risk of the peat from land firing by improving water holding capacity of the organic material particularly those litters lying on the soil surface which acts as the main source of peat burning [27] [28]. Regression analyses indicates that the dosages of MPMs were linearly correlated with the time of fire spread (Figure 5). The more MPMs is added the longer time needed by the fire to spread out. This evidence leads to the assumption that the phenomenon was taken place due to the increase of water contents in the organic media after the MPMs addition. Data shown in Table 4 support this assumption in which all MPMs studied have WHC $(39.10 \%-60.50 \% \mathrm{w} / \mathrm{w})$ higher than the original organic media before the MPMs addition (14.4\% w/w).

Table 4. Water holding capacity of MPMs studied.

$\begin{array}{cc}\text { MPMs } & \text { Water Holding Capacity (\%) } \\ \text { EFBOPB } & 39.10 \\ \text { Zeolite } 60-80 \text { mesh } & 43.59 \\ \text { Zeolite } 80-100 \text { mesh } & 49.22 \\ \text { Zeolite } 100-150 \text { mesh } & 60.50 \\ \text { Zeolite:EFBOPB (50:50) } & 44.16 \\ \text { Zeolite:EFBOPB (75:25) } & 44.22\end{array}$

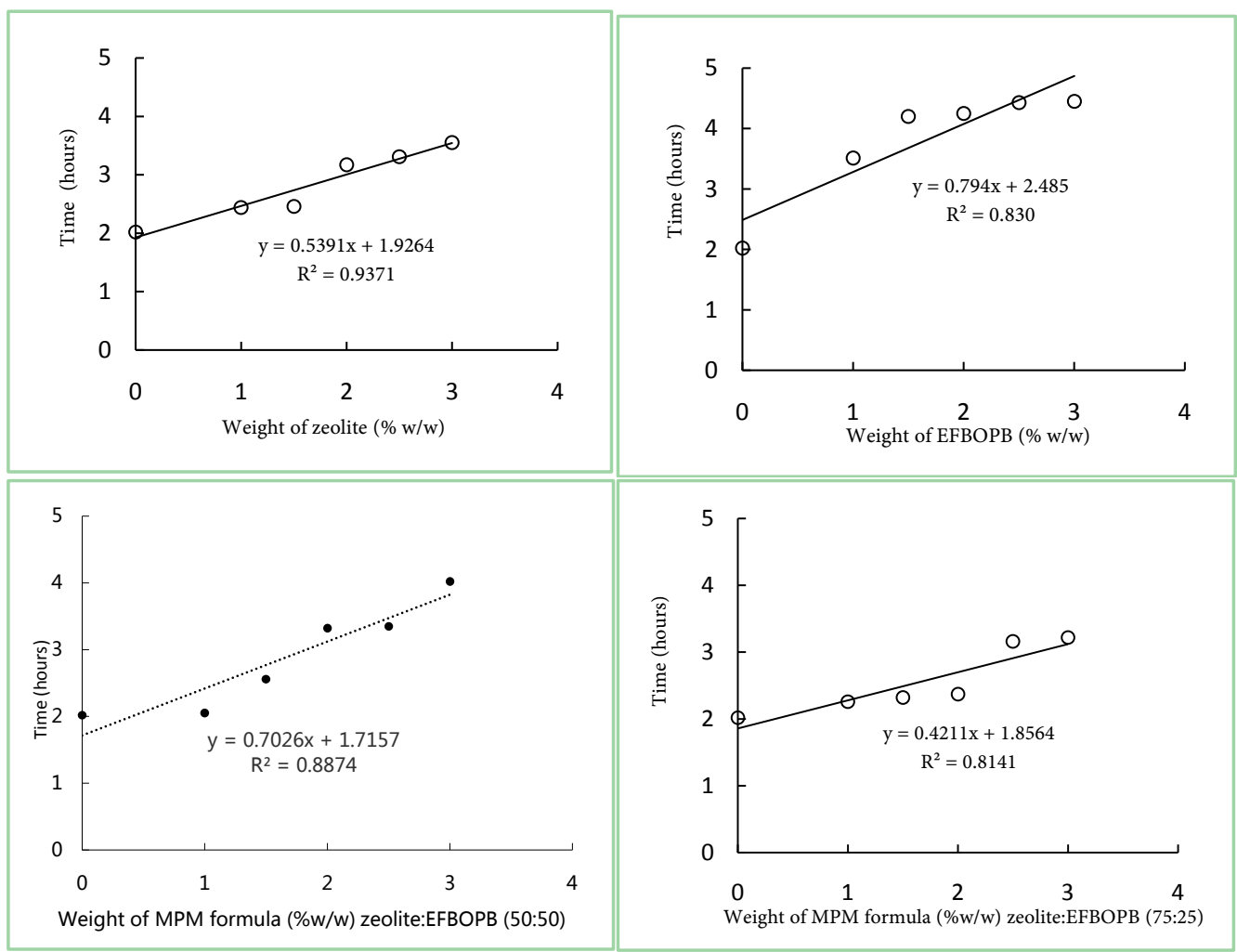

Figure 5. Relationships of the MPMs dosages with burning time of organic materials. 
Although, the data have not reached a maximum level for the dosage's effect, the slope of the equation indicating that the dosage of EFBOPB would be lower than the zeolite and that of the formula MPMs 75:25 would be higher than the 50:50 formula to achieve the same time of fire spread. This evidence shows that the contribution of EFBOPB on slowing down the spread of fire is higher than that of zeolite. However, further field study is necessary to validate the effects of the formulated MPMs on peat degradation protection upon intensive agricultural practices.

\section{Conclusion}

Efforts to overcome the detrimental risk of peat soils used for intensive agricultural practices, including oil palm plantation will to some extend be focused on the application of technology that is able to reduce dry peat and GHG emission potential. The results of this current study indicate that the use of MPMs consisting of Bayah zeolite and EFBOPB could be used to achieve the forementioned target as the technology proved of having beneficial characteristics to adsorb GHG in the forms of $\mathrm{CO}_{2}$ and $\mathrm{NH}_{3}$ and improving water holding capacity of the peat materials. However, the study awaits further observation in the field to evaluate the effectiveness of the technology under field conditions.

\section{Acknowledgements}

The authors wish to thank to The Indonesia Estate Crop Fund Management Agency for Palm Oil, Ministry of Finance, the Republic of Indonesia for valuable supports in funding this research, Contract No. PRJ-14/DPKS/2020.

\section{Conflicts of Interest}

The authors declare no conflicts of interest regarding the publication of this paper.

\section{References}

[1] Worsten, J.H.M., Clymans, E., Page, S.E. and Limin, S.H. (2008) Peat-Water Interrelationships in a Tropical Peatland Ecosystem in Southeast Asia. Catena, 73, 212-224. https://doi.org/10.1016/j.catena.2007.07.010

[2] Hooijer, A., Page, S.E., Jauhiainen, J., Lee, W.A., Lu, X.X., Idris, A. and Anshari, G. (2012) Subsidence and Carbon Loss in Drained Tropical Peatlands. Biogeosciences, 9, 1053-1071. https://doi.org/10.5194/bg-9-1053-2012

[3] Ritung, S., et al. (2019) Map of Indonesia Peatland, Scale 1:50.000. Indonesian Center for Agricultural Land Resources Research and Development, Bogor.

[4] Koh, L.P., Meitinen, J., Liew, S.C. and Ghazoul, L.J. (2011) Remotely Sensed Evidence of Tropical Peatland Conversion to Oil Palm. Proceedings of the National Academy of Sciences of the United States of America, 108, 5127-5132. https://doi.org/10.1073/pnas.1018776108

[5] Sangok, F.E., Maie, N., Meiling, L. and Watanabe, A. (2017) Evaluation on the Decomposability of Tropical Peat Soils after Conversion to an Oil Palm Plantation. 
Science of the Total Environment, 587-588, 381-388.

https://doi.org/10.1016/j.scitotenv.2017.02.165

[6] Tonks, A.J., Aplin, P., Beriro, D.J., Cooper, H., Evers, S., Vane, C.H. and Sjogersten (2017) Impacts of Conversion of Tropical Peat Swamp Forest to Oil Palm on Peat Organic Chemistry, Physical Properties, and Carbon Stocks. Geoderma, 289, 36-45. https://doi.org/10.1016/j.geoderma.2016.11.018

[7] Marwanto, S., Sabiham, S. and Funakawa, S. (2019) Importance of $\mathrm{CO}_{2}$ Production in Subsoil Layers of Drained Tropical Peatland under Mature Oil Palm Plantation. Soil \& Tillage Research, 186, 206-213. https://doi.org/10.1016/j.still.2018.10.021

[8] Leng, L.Y., Ahmed, O.H. and Jalloh, M.B. (2018) Brief Review on Climate Change and Tropical Peatlands. Geoscience Frontiers, 10, 373-380.

https://doi.org/10.1016/j.gsf.2017.12.018

[9] Osaki, M., Tsuji, N., Foead, N. and Rieley, J. (2021) Tropical Peatland Eco-Management. Springer, Singapore. https://doi.org/10.1007/978-981-33-4654-3

[10] Grootjans, A.P. (2017) Paludiculture-Productive Use of Wet Peatlands. Restoration Ecology, 25, 661-663. https://doi.org/10.1111/rec.12568

[11] Sabiham, S., Winarna, Pulunggono, H.B. and Novarina, D. (2016) What Is the Forward on Indonesian Peatland? 15th International Peat Congress, Kuching, 15-19 August 2016, 39-42.

[12] Santi, L.P. and Goenadi, D.H. (2018) The Use of Exo-Polysaccharide-Producing Endophytic Microbe as Bio-Ameliorant in Peat Soils. Proceeding at International Oil Palm Conference, Medan, 17-19 July 2018, 214-224.

[13] Hirata, M. and Jimbo, I. (2016) Utilization of Concrete Waste to Capture $\mathrm{CO}_{2}$ with Zeolite. Proceedings of the School of Engineering, 41, 9-13.

[14] Shen Y., Zhu, L., Cheng, H., Yue, S. and Li, S. (2017) Effects of Biochar Application on $\mathrm{CO}_{2}$ Emissions from a Cultivated Soil under Semiarid Climate Conditions in Northwest China. Sustainability, 9, 1482.

[15] Kalbuadi, D.N., Goenadi, D.H., Santi, L.P. and Nurtjahja, L.R. (2019) The Potential Use of Natural Clinoptilolite Zeolite for Crude Oil Spill Removal from Sea Water. Journal of Minerals and Materials Characterization and Engineering, 7, 446-453. https://doi.org/10.4236/jmmce.2019.76031

[16] Srivatsav, P., Bhargav, B.S., Shanmugasundaram, V., Arun, J., Gopinath, K.P. and Bhatnagar, A. (2020) Biochar as an Eco-Friendly and Economical Adsorbent for the Removal of Colorants (Dyes) from Aqueous Environment: A Review. Water, 12, 3561 .

[17] Goenadi, D.H. (2020) BioChar: Teknologi Pembenah Tanah Nabati. IPB Press, Bogor.

[18] Bacskai, I., Madar, V., Fogarassy, C. and Toth, L. (2019) Modeling of Some Operating Parameters Required for the Development of Fixed Bed Small Scale Pyrolysis Plant. Resources, 8, 1-15. https://doi.org/10.3390/resources8020079

[19] Dogan, A.U., Dogan, M., Onal, M., Sarikaya, Y., Aburub, A. and Wurster, E.D. (2006) Baseline Studies of the Clay Mineral Society Source Clays: Specific Surface Area by the Brunauer Emmett Teller (BET) Method. Clay and Minerals, 54, 62-66. https://doi.org/10.1346/CCMN.2006.0540108

[20] Walton, K.S. and Snurr, R.Q. (2007) Applicability of the BET Method for Determining Surface Areas of Microporous Metal-Organic Frameworks. Journal of the American Chemical Society, 129, 8552-8556. https://doi.org/10.1021/ja071174k

[21] Cullity, B.D. and Stock, S.R. (2001) Elements of X-Ray Diffraction. Prentice Hall, 
Upper Saddle River.

[22] Kaech, A. (2013) An Introduction to Electron Microscopy Instrumentation, Imaging and Preparation. Center for Microscopy and Image Analysis, University of $\mathrm{Zu}$ rich, Zurich, 1-28.

http://www.zmb.uzh.ch/static/bio407/assets/Script_AK_2014.pdf

[23] Santi, L.P., Goenadi, D.H. and Osaki, M. (2021) Zeolites and Aggregate-Stabilizing Microbes for Reducing the Degradation and Carbon Emissions in Tropical Peatlands. In: Osaki, M., Tsuji, N., Foead, N. and Rieley, J., Eds., Tropical Peatland Eco-Management, Springer, Singapore, 327-335.

[24] Ramadhan, M.L., Palamba, P., Imran, F.A., Kosasih, E.A. and Nugroho, Y.S. (2017) Experimental Study of the Effect of Water Spray on the Spread of Smoldering in Indonesian Peat Fires. Fire Safety Journal, 91, 671-679.

https://doi.org/10.1016/j.firesaf.2017.04.012

[25] Kusin, F.M., Izzati, N., Yusuff, F.M. and Awang, M. (2015) The Impact of Nitrogen Fertilizer Uses on Greenhouse Gas Emissions in an Oil Palm Plantation Associated with Land Use Change. Atmósfera, 28, 243-250.

https://doi.org/10.20937/ATM.2015.28.04.03

[26] Intergovernmental Panel on Climate Change (IPCC) (2006) Guidelines for National Greenhouse Gas Inventories. Volume 4: Agriculture, Forestry and Other Land Use. Chapter 11. $\mathrm{N}_{2} \mathrm{O}$ Emissions from Managed Soils, and $\mathrm{CO}_{2}$ Emissions from Lime and Urea Application.

[27] Usup, A., Hashimoto, Y., Takahashi, H. and Hayasaka, H. (2004) Combustion and Thermal Characteristics of Peat Fire in Tropical Peatland in Central Kalimantan, Indonesia. Tropics, 14, 1-19. https://doi.org/10.3759/tropics.14.1

[28] Pulunggono, H.B., Cahyahusna, A., Anwar, S., Sumawinata, B., Taniwiryono, D., Siswanto, Wiadiastuti, H., Tambusai, N., Mubarok, H. and Sabiham, S. (2020) A Review of Carbon-Dioxide Gas Emissions from Peatlands to Determine the Emissions Factor for Drained Peatlands for Oil Palm Plantations in Indonesia. Journal of Oil Palm and Palm Oil Research, 1, 23-39.

https://creativecommons.org/licenses/by-nc/4.0 